\title{
Guidelines for e-Startup Promotion Strategy
}

\author{
Marco D’Avino',Valerio De Simone², Marco lannucci ${ }^{3}$, Massimiliano Maria Schiraldi $^{4}$
}

\begin{abstract}
Startup businesses have always played an important role in the global economy, but recently their importance has grown significantly. For this reason, governments around the world have amended regulation and created incentives to encourage their development. However, statistics show that startups have an extremely high mortality rate, often due to a lack of strategic planning, wrong marketing investments or inefficient resource allocation. The purpose of this paper is to propose a decision-driven tool which will enable the creation of a successful promotional strategy. The proposed strategy is a three-stage process allowing startups to gradually eliminate non-optimal advertising formats. The first stage focuses on the analysis of the e-market where the startup operates. The second stage is dedicated to the economic environment that the new company will face relative to its available resources. Its aim is to reject overly expensive advertising formats by linking costs to availability of funds. The third and last stage is a cost effectiveness analysis, allowing the entrepreneur to identify the best advertising formats and using an impact-factor as a proxy of effectiveness. The proposed methodology has been applied to the case of an Italian early-stage startup for validation.
\end{abstract}

Keywords: start-up; promotional strategy; marketing; advertising formats.

1,2,3,4 University of Rome “Tor Vergata”, Department of Enterprise Engineering, Operations Management Research Group. Via del Politecnico I, 00133 Rome, Italy. Phone: +39 06 725972 16. E-mail: valerio.de.simone@uniroma2.it (Corresponding author). 


\section{Introduction}

Startups are becoming increasingly important in today's economy: fast responsiveness, growth-oriented strategy and high flexibility help these companies overcome financial crisis better than bigger firms with slower response times (Romanelli, 1989; Marques \& Ferreira, 2009). Indeed, startup growth is encouraged by almost all governments in the developed countries, for example by simplifying regulation or allocating special funds:

- $\quad$ In the U.S., since Obama became President, over three million new jobs and a revenue of several billion dollars have been generated through this enterprise model (Cerati, et al., 2012);

In Europe, the startup ecosystem is growing (Herrmann, Marmer, Dogrultan, \& Holtschke, 2012) with Berlin, London and Paris home to significant numbers of startups (Cerati, et al., 20I2). In 2012 London was the top ranked city in Europe in terms of capital raised per startups, averaging $\$ 1.15 \mathrm{M}$ dollars per venture. London also had the highest percentage of serial entrepreneurs (42\%). Despite these figures, European cities are still way behind Silicon Valley where the average capital raised per startup is $\$ 3 M$ and $56 \%$ of entrepreneurs are serial entrepreneurs - figures which have shown significant growth year on year.

Yet this strong growth goes hand in hand with a high mortality rate, as evidenced by the U.S. data from 2012 (Romanelli, I989; Bureau of Labor Statistics, 2012):

- $\quad 25 \%$ in the first year;

- $\quad 45 \%$ by the fifth year, with an average of $55 \%$ for

ICT startups and a peak of $71,4 \%$ in construction sector;

- $\quad 80 \%$ by the tenth year.
There are several reasons new companies find it difficult just staying in business, with the ability to raise capital cited as the primary cause of failure, followed by bureaucracy and strong competition (Schwienbacher \& Larralde, 2010;Wong, Bhatia, \& Freeman, 2010; Kortum \& Lerner, 2000; Sohl \& Rosenberg, 2003; Magri, 2009). In fact company's growth (and survival) is highly correlated with the ability to raise new funds, but only startups with a large potential market and remarkable KPIs (e.g. number of daily users, transactions) are attractive for investors (Wong, Bhatia, \& Freeman, 2010; Schwienbacher \& Larralde, 20I0). Furthermore many other aspects impact on the fund rising capabilities: intellectual capital (Alberghini, Cricelli, \& Grimaldi, 2013; Steenkamp \& Kashyap, 2010; Tan, Plowman,\&Hancock,2008;Zerenler,Hasiloglu,\&Sezgin,2008), entrepreneur experiences (Lasch, Le Roy, \& Yami, 2007; Song, Bijl van der, \& Halman, 2008) and innovation (Groenewegen \& de Langen, 2012; Maldonado, Dias, \& Varvakis, 2009) are all key drivers as well as their promotion capabilities (Magri, 2009). Indeed, to raise new capital, a startup has to increase its visibility within the investor market, hence having the correct advertising strategy is critical. Ben Silbermann, CEO of Pinterest - the third social-network in the world by active-users - stressed that "...the secret behind Pinterest's growth was marketing, not engineering...". The aim of this paper is to provide entrepreneurs with a new approach to identify the most appropriate promotion activities, thereby increasing the likelihood of their own startup's survival. As previously stated, promotion and marketing in general is widely considered as the key to survival, development and success of small or new ventures (Bjerke \& Hultman, 2004; Carson, Cromie, McGowan, \& Hill, 1995; Lewrick, Omar, \& Williams, Jr., 20II) and a number of studies have been conducted which focus on its importance. Despite the wealth of literature on this topic and the criticality of a good marketing strategy, enterprises often diverge from textbook guidelines (McGrath, Tsai, Venkataraman, \& MacMillan, 1996). Up until the 90 s it was widely assumed that small or new ventures required a simplified version of the more "sophisticated" marketing practices that were developed for larger companies (Kraus, Harms, \& Fink, 20I0). To this extent, the "entrepreneurial marketing" (EM) concept was introduced: Bjerke (Bjerke \& Hultman, 2004) defines EM as "marketing of small firms growing through entrepreneurship", similarly Morris (Morris, Schindehutte, \& LaForge, 2002) as "the unplanned, non-linear, visionary marketing actions of the entrepreneur" and Stokes (Stokes, 2002) as "marketing carried out by entrepreneurs or ownermanagers of entrepreneurial ventures". Finally Kraus (Kraus, Harms, \& Fink, 2010) suggests a definition focused on a marketing and entrepreneur concept, defining EM as "an organizational function and a set of processes for creating, communicating and delivering value to customers and for

ISSN: 07I 8-2724. (http://www.jotmi.org) 
managing customer relationships in ways that benefit the organization and its stakeholders, and that is characterized by innovativeness, risk-taking, proactiveness, and may be performed without resources currently controlled.". Moving to more practical aspects, today the three best-known forms of EM are buzz marketing, guerrilla marketing and viral marketing (Kraus, Harms, \& Fink, 20 I0).

Buzz marketing: This approach uses the recipient's e-mail or cell phone networks to generate a "buzz" around a product or a brand, thereby growing customers' interest in it. These actions can be for example an event or an activity that causes excitement, generating publicity, enthusiasm and a desire for more information on the product which leads to brand-building (Ahuja, Michelis, Walker, \& Weissbuch, 2007). Some studies, backed by real statistics (i.e. Nielsen BuzzMetrics), show that this approach is not as efficient for every type of product or service. In fact to be a good candidate for buzz marketing a product has to be both unique in some features compared to competitors (e.g. functionality, ease of use, price), and highly visible. Harry Potter or Pokémon promotion campaigns have been popular examples of effective buzz marketing (Dye, 2000);

- Guerilla marketing: This term was popularized by Jay Conrad Levinson in 1984 (Levinson, Guerrilla Marketing: Secrets for making big profits from your small business, 1984). It originally identified a variety of low-cost and highimpact marketing techniques that allow small companies and/ or individuals to act like big companies. Today this concept has been adapted and applied to the modern economy, introducing an extensive use of new social and mobile channels. One of the most successful adopters of guerilla marketing techniques is Red-Bull, with its unconventional promotional strategy, along with other big firms, such as Nike or McDonalds (Levinson \& Levinson, The best of guerilla marketing: Guerilla Marketing remix, 20I I);
- Viral marketing: This term describes a form of marketing that uses social networks (family, friends, neighbors, colleagues) to draw attention to brands, products or campaigns by spreading messages as quickly as a virus (Phelps, Lewis, Mobilio, Perry, \& Raman, 2004). It is important to note that both Buzz andViral marketing can be considered forms of word-of-mouth marketing,but viral is the impersonal (lacking face-to-face communication), technology-backed version of buzz marketing (Mohr \& Spekman, 1994). More recent approaches to viral marketing suggest a hybrid model that uses traditional media to seed the early-stages of campaigns. Nonetheless the success of the campaign relies heavily on social-sharing capabilities of social networks (Watts \& Peretti, 2007). A classic example of effective viral marketing is Hotmail.com's "Get your private, free email at http://www.hotmail.com" campaign which reached 12 million users in less than 18 months (Porter \& Golan, 20120).

The main advantage of each of the approaches discussed is the extraordinarily low cost of implementation through the use of new, inexpensive communication channels, i.e. the internet and email (Dobele, Toleman, \& Beverland, 2005; Zilber \& Braz de Araújo, 2012). These features make EM ideal for startups.

As mentioned above, one of the objectives of this paper is to understand the optimal advertising strategy for startup visibility and operational KPls to allow higher possibility to raise new capitals and succeed.

The paper is organized as follows: the three-stage model explanation and formalization is presented in section 2, while section 3 shows a practical application of the model, analyzing an early-stage ICT startup, operating in Italy. Finally, section 4 includes conclusions, limitations and future developments of this research.

\section{Method}

The proposed methodology is based on a three-stage evaluation approach of advertising formats in order to identify the best one for any new venture. As is shown in Figure I, it works as a funnel: at each stage some advertising formats are filtered and excluded in order to leave most suitable choice in each case. The three filters are:

I. Feasibility: given the market context, focus only on the adaptable formats (e.g. avoid choosing a channel which is too technologically advanced for country in question).

2. Efficiency: given the startup's resources, select the most affordable promotional formats.

3. Effectiveness:choose the best advertisement system from the most feasible and affordable options, analyzing the effectiveness as the ratio between impact and costs.

ISSN: 07I 8-2724. (http://www.jotmi.org) 


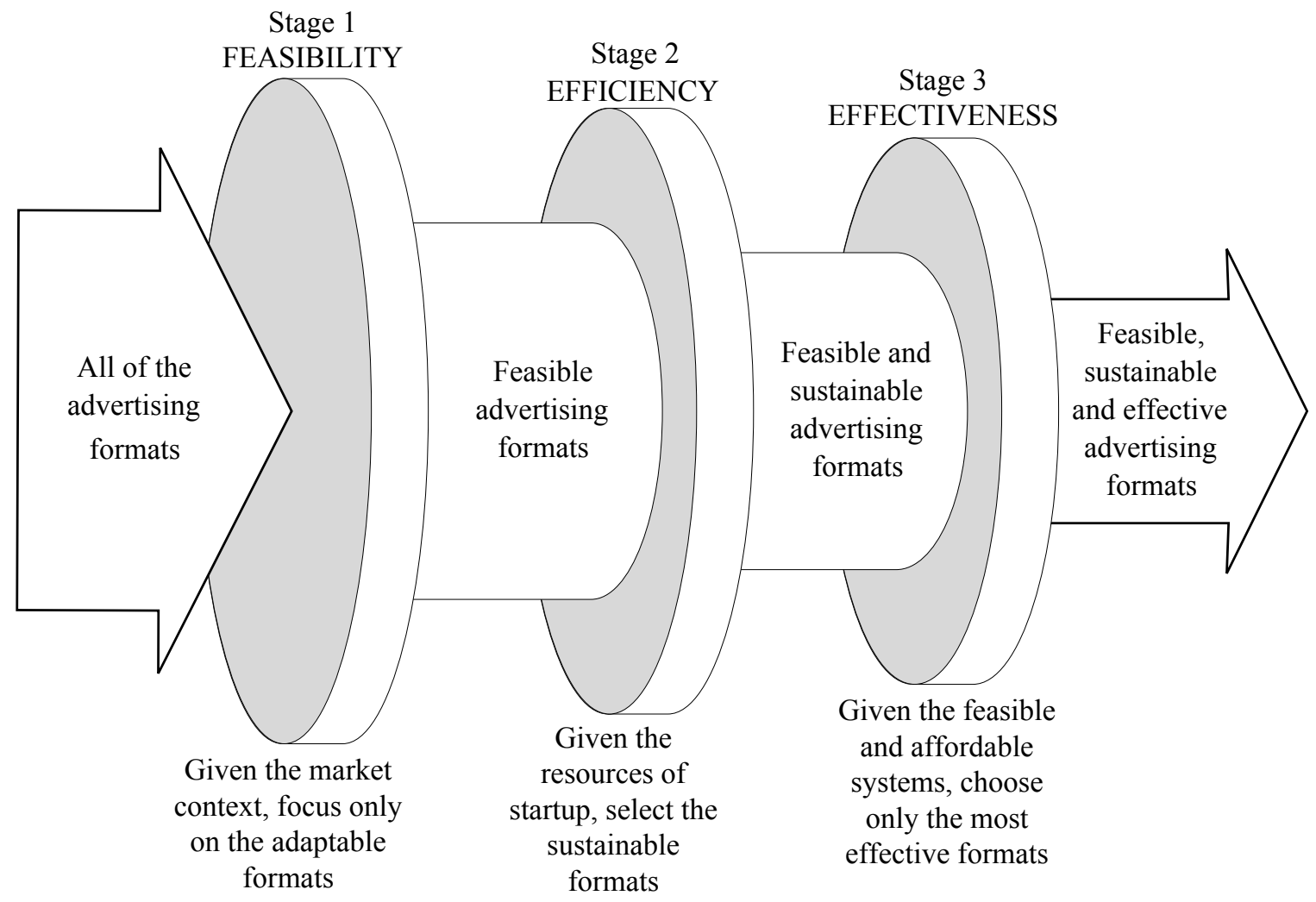

Figure 1. Three-stage evaluation model. 


\section{I Feasibility stage}

To ensure EM strategy effectiveness, target people must have access to the selected marketing channels and be able to use them. For example, if an entrepreneur promotes his product via in-app advertising in a market where people do not use smartphones he will fail because his promotional strategy is intrinsically wrong: his potential customers do not have access to his chosen marketing channel. To overcome this issue, a preliminary market analysis is required in order to understand the technology adoption and usage. The analysis proposed uses an index which allows one to measure adoption of technology. The most common indices in literature are metrics of the "digital divide" (Hüsing \& Selhofer, 2004), a term which quantifies the gap between individuals, households, businesses and regions in both their ease of access to information and level of communication technologies available (Organisation for Economic Co-operation and Development, 200I). Given this definition, the main limitation of digital divide indices is related to the lack of importance attributed to user's skill with ICT services. Furthermore, a different index has been used in this paper: the ICT Development Index (hereinafter referred to as IDIC). IDIC is a composite index combining II indicators, as shown in Table I, into one benchmark measure that serves to monitor and compare developments in ICT across countries. The IDIC was developed by ITU (Information Telecommunication Society) in 2008 and first presented in the 2009 edition of Measuring the Information Society. It was established in response to ITU Member States' request to develop an ICT index and publish it regularly. A single indicator cannot track progress in all three components (access, usage and skills) of the ICT development process, thus requiring the construction of a composite index such as the IDIC. The IDIC aims to capture the evolution of technology uptake in society at different stages of development and also considers the emergence of new technology. Based on this conceptual framework, the IDIC is divided into the following three sub-indices (International Telecommunication Union, 2012):

- $\quad$ Access sub-index: This sub-index captures ICT readiness and includes five infrastructure and access indicators: fixed-telephone subscriptions, mobile cellular telephone subscriptions, international Internet bandwidth per Internet user, percentage of households with a computer and percentage of households with Internet access;

- $\quad$ Use sub-index:This sub-index captures ICT intensity and includes three ICT intensity and usage indicators: percentage of internet users, fixed (wired)-broadband subscriptions, and active mobile broadband subscriptions;

- $\quad$ Skills sub-index: This sub-index captures ICT capability or skills as an indispensable input indicator. It includes three proxy indicators: adult literacy, gross secondary enrolment and gross tertiary enrolment. Seeing that it is made up of proxies, its weight in the computation of the IDIC is lower than that given to the other two sub-indices.

\begin{tabular}{|c|l|l|}
\hline Sub Index & Indicator & $\begin{array}{l}\text { Indicator } \\
\text { weight }\end{array}$ \\
\hline \multirow{4}{*}{$\begin{array}{c}\text { ICT access } \\
(40 \%)\end{array}$} & Fixed-telephone lines per I00 inhab. & $20 \%$ \\
\cline { 2 - 3 } & Mobile-cellular telephone subscriptions per I00 inhab. & $20 \%$ \\
\cline { 2 - 3 } & International internet bandwidth per internet user & $20 \%$ \\
\cline { 2 - 3 } & Percentage of households with a computer & $20 \%$ \\
\cline { 2 - 3 } & Percentage of households with internet access & $20 \%$ \\
\hline \multirow{2}{*}{$\begin{array}{c}\text { ICT use } \\
(40 \%)\end{array}$} & Percentage of individuals using the internet & $33 \%$ \\
\cline { 2 - 3 } & Fixed (wired)-broadband internet subscriptions per I00 inhab. & $33 \%$ \\
\cline { 2 - 3 } $\begin{array}{c}\text { ICT skills } \\
(20 \%)\end{array}$ & Active mobile-broadband subscriptions per I00 inhab. & $33 \%$ \\
\cline { 2 - 3 } & Sdult literacy rate & $33 \%$ \\
\cline { 2 - 3 } & Secondary gross enrolment ratio & $33 \%$ \\
\hline
\end{tabular}

Table I. ICT Development index: indicators and weights. Source: Measuring the Information Society 20 I2, ITU (International Telecommunication Union, 2012).

ISSN: 07I 8-2724. (http://www.jotmi.org)

Journal of Technology Management \& Innovation (c) Universidad Alberto Hurtado, Facultad de Economía y Negocios. 
In order to develop this analysis it is essential to have two indices: an indicator of ICT capabilities and an advertising format score for measuring technological development. Both are necessary to find the right match between the format and the consumer and avoid unsuitable channels for target users. Table 2 lists most common advertising formats (Nielsen, 20I I) (PricewaterhouseCoopers LLP, 20I I) and introduces a new index, called IDIF, that measures the technological evolution of the advertising formats. To maintain the analogy with IDIC, IDIF assumes a value between $I$ and 10 and is proportional to IT evolution.Authors assigned a specific IDIF value to the formats in the first column, after first grouping them by marketing channel (traditional, web I.0, web 2.0) and then by instrument required (mobile phone, TV, etc.), sorting each "cluster" with respect to the instrument's level of technological evolution. For example the "Traditional,TV" cluster has a higher IDIF value than "Traditional, newspaper", which uses print.
In the first stage we compare IDIC and IDIF in order to filter out advertising formats that have IDIC lower than IDIF. In particular, context is defined with respect to the market served by the startup, referring to its characteristics in terms of ICT knowledge and not necessarily to its geographical and technological boundaries. The underlying hypothesis is that not having a computer is a sufficient condition to not use internet but, at the same time, having a computer is only a necessary condition to use the internet. Therefore a format with IDIF lower than IDIC can still be exploitable for the marketer, unlike than formats with higher IDIF.

\begin{tabular}{|c|c|c|c|}
\hline Ad Format & Marketing Channel & $\begin{array}{l}\text { Instrument } \\
\text { Required }\end{array}$ & $\begin{array}{l}\text { Estimated } \\
\text { IDI Range }\end{array}$ \\
\hline Outdoor & \multirow{6}{*}{ Traditional } & Nothing & 0 \\
\hline Newspaper & & Paper & $1 / 2$ \\
\hline Magazines & & & \\
\hline Radio & & Radio & $2 / 3$ \\
\hline TV & & TV & $3 / 4$ \\
\hline Mobile (SMS) & & Mobile phone & $4 / 5$ \\
\hline Sponsorship & \multirow{5}{*}{ Web I.0 } & \multirow{5}{*}{ Computer + Internet (with slow connection) } & \\
\hline Display Ads & & & $5 / 6$ \\
\hline Rich Media & & & \\
\hline Direct Mail & & & $6 / 7$ \\
\hline SEO \& SEM & & & \\
\hline Blogging & \multirow{4}{*}{ Web 2.0} & Computer + Internet (with fast connection) & $7 / 8$ \\
\hline Social Media & & & \\
\hline Digital Video & & & \\
\hline Mobile (App) & & Smartphone & $8 / 9$ \\
\hline
\end{tabular}

Table 2.Advertising format ordered by IDIF value. 
IDIC values are calculated and published every year by ITU; nevertheless a short reflection could be necessary. The aforementioned document reports IDIC values related to the entire nation, so they are derived from the average between high-developed regions and low-developed ones. National heterogeneity is an important element in choosing advertising formats. In fact two startups operating in the same nation could supply totally different markets, characterized by deep differences in terms of ICT usage and development. For this reason the startup can revise and eventually rectify the national IDIC value in order to make it more specific for the region where the startup is operating. It is reasonable to assume that metropolitan areas are characterized by an IDIC which is higher than the IDIC of the nation, while the opposite can be assumed for rural areas (International Telecommunication Union, 20I2). Furthermore, by using the IDIC value, there is a clear need to decline promotional strategy for the specific target market.

In order to create an analytic model of the first stage described above, a simple if-function can be used (described in Figure 2) where $\varphi \mathrm{i}$ indicates the generic advertising format and IDIF and IDIC are as described in the previous paragraph.

\subsection{Efficiency stage}

The second stage focuses on the cost trade-off analysis. Similar advertising formats may have very different costs, for example digital video advertising (e.g. advertising on YouTube or Vimeo) is much cheaper than video of the same length on TV, which, on the other hand, has a higher conversionrate and credibility (Johnson \& Kaye, 2002). Many times the economic aspect can be binding constrain in a startup because entrepreneurs could not choose expensive formats. Defining what "binding" means could be complicated, because each startup has different resources to invest in promotion and thus indicating an absolute amount to invest is obviously impossible. Having said that, different theories agree in defining promotion investment as a constantpercentage of a firm's available resources and all of them identify an average investment ranges between $5 \%$ and $15 \%$ (Beesley, 20I2; Christine, 2013). Other evidence, however, shows that this value can be as high as $30 \%$ in early-stage startups. Promotional investments in the above range should be considered more as an indication than a rule. In fact each specific entrepreneur will decide their optimal investment depending on conditions at the time, conditions which are very complex to include into a mathematical model because of the very high number of variables involved. Referring to a startup's balance sheet, "available resources" can reasonably translate in "equity" and "liability". Profit or cash-flow are not usually used as these values are usually negative for most early-stage startups.

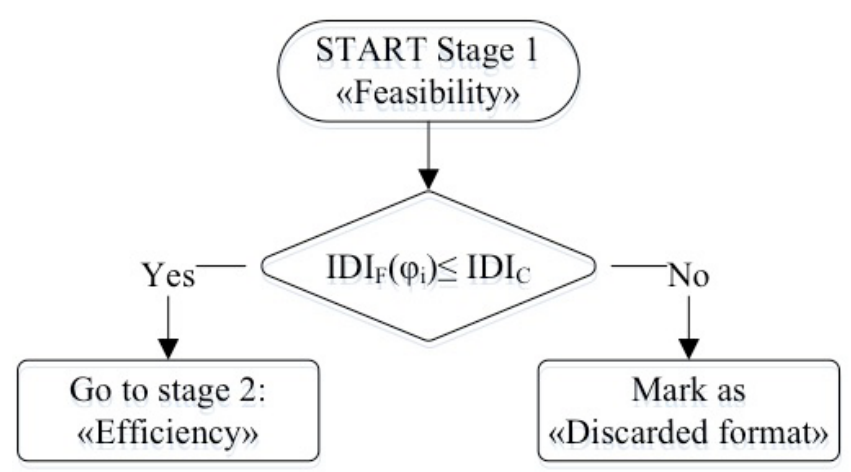

Figure 2. Stage I « Feasibility » flowchart.

ISSN: 07 I 8-2724. (http://www.jotmi.org) 
The flowchart in Figure 3 exemplifies the process used to evaluate which formats are too expensive for the startup. Variables expressed in the flowchart represent:

- $\quad B \equiv$ Budget for advertising campaign (calculated as a percentage of the startup's resources);

- $\quad M \equiv$ Target market dimensions. Costs related to an advertising campaign are mainly variable costs, and for this reason it is important to be explicit about market's dimensions: comparing the cost of two promotion campaigns where target markets are different in size would be wrong. This variable can be expressed as the number of target users of the promotional campaign;

- $\quad C(\varphi \mathrm{i} \mid \mathrm{M}) \equiv$ The cost of a campaign using advertising format $\varphi$ i with dimension $M$.

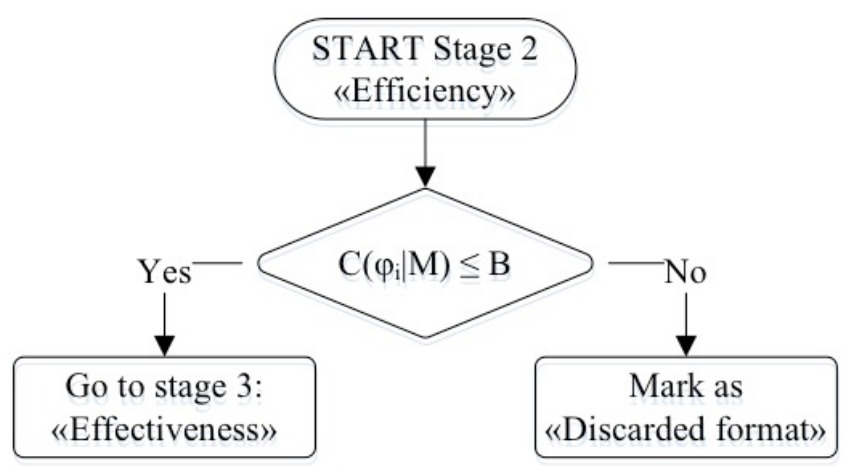

Figure 3. Stage 2 « Efficiency » flowchart.

\subsection{Effectiveness stage}

The last stage of the approach is different from the previous two because now, all the formats are considered suitable in stage one and two, are sorted by effectiveness. This effectiveness is computed as a ratio: impact / costs. The overall cost of each format is not difficult to identify and it has already been calculated in the previous stage (i.e. $C(\varphi \mathrm{i}$ (M) for each format $\varphi \mathrm{i})$. The difficulty is in understanding and measuring the impact of an advertising format, since the same format could have different impacts depending on the business where it is applied. Table 3 provides a simple framework to classify startups based on two metrics: application-type and purpose-type.

\begin{tabular}{|l|l|l|}
\hline & Software Application & $\begin{array}{l}\text { Web \& Mobile } \\
\text { Application }\end{array}$ \\
\hline Specific & Specific & Specific \\
Purpose & Desktop & Mobile \\
\hline Generic & Generic & Generic \\
Purpose & Desktop & Mobile \\
\hline
\end{tabular}

Table 3. Startup classification for application and purpose. 
The $\mathrm{x}$-axis represents the application-type which is closely connected to the features of the startup output. The $y$-axis represents the purpose-type segmentation that is connected to market-target features. This matrix is inspired by (Venture Capital Monitor, 20II) and classifies startups into four categories:

- $\quad$ Specific desktop: startup develops software for computer (desktop), oriented to a niche market with specific needs (specific);

- $\quad$ Specific mobile: startup develops applications for mobile devices (mobile), oriented to a niche market with specific needs (specific);

- $\quad$ Generic mobile: startup develops applications for mobile devices (mobile), oriented to a mass market (generic); - Generic desktop: startup develops software for computer (desktop), oriented to a mass market (generic).
This classification is designed to organize formats with similar effectiveness in specific business. For example mass media (e.g. TV, Radio, and Social Network) should have a minor impact for business focused on a specific market segment compared to other formats that are specific to that segment (e.g. specialized magazines). According to this we can also infer that social media has a relatively low impact with specific-purpose businesses and, at the same time, that mobile related advertising formats have a relatively high impact for startups which specialize in mobile applications development. This phenomenon can be explained by defining the effectiveness of format $\varphi$ i as:

$$
\eta\left(\varphi \_\mathrm{i}\right)=\left(\operatorname{impact}\left(\varphi_{-} \mathrm{i}\right)\right) / \operatorname{cost}\left(\varphi_{-} \mathrm{i}\right)(1)
$$

Formula (I) suggests that effectiveness depends directly on impact, but this value is closely connected to the startups classification reported in Table 3. Combining advertising formats list proposed in Table 2 and startups classification proposed in Table 3, it is possible to obtain the following Table 4. This table can be used by startups to evaluate effectiveness of advertising formats and to adjust format for specific startup types, putting a higher importance to formats with sign "+".

\begin{tabular}{lcccc} 
Ad Format & Specific Desktop & Specific Mobile & Generic Desktop & Generic Mobile \\
\hline Outdoor & & & & \\
Newspaper & & & & \\
Magazines & + & & & \\
Radio & & & & + \\
TV & & + & & \\
Mobile (SMS) & & & & \\
Sponsorship & + & & & + \\
Display Ads & & & & + \\
Rich Media & & & + & + \\
Direct Mail & & & + & + \\
SEO \& SEM & & & + \\
Blogging & + & & + \\
Social Media & & + & & + \\
Digital Video & & & & + \\
Mobile (App) & & & & + \\
\hline
\end{tabular}

Table 4.Advertising format impact corrector-factor for each cluster of startups.

ISSN: 07 I8-2724. (http://www.jotmi.org) 
In the following Figure 4, as done for the previous stages, the flowchart of "effectiveness stage" is shown.

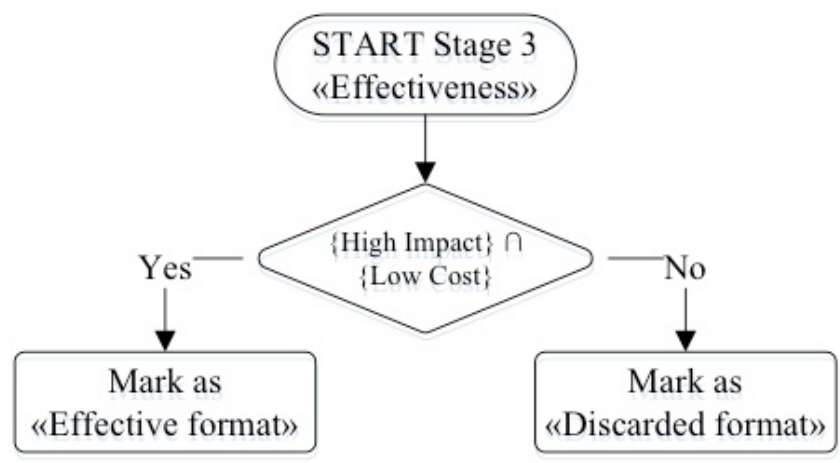

Figure 4. Stage 3 « Effectiveness » flowchart.

\subsection{Conclusive formalization}

Figure 5 shows the full flowchart of the approach, built by combining the flow chart of each stage detailed above. To obtain the complete set of "effective formats", the process has to be iterated for each format under consideration.

As one may observed, despite the process is made up of three different sub-processes it is simple and lean, from both a logical and pragmatic side.

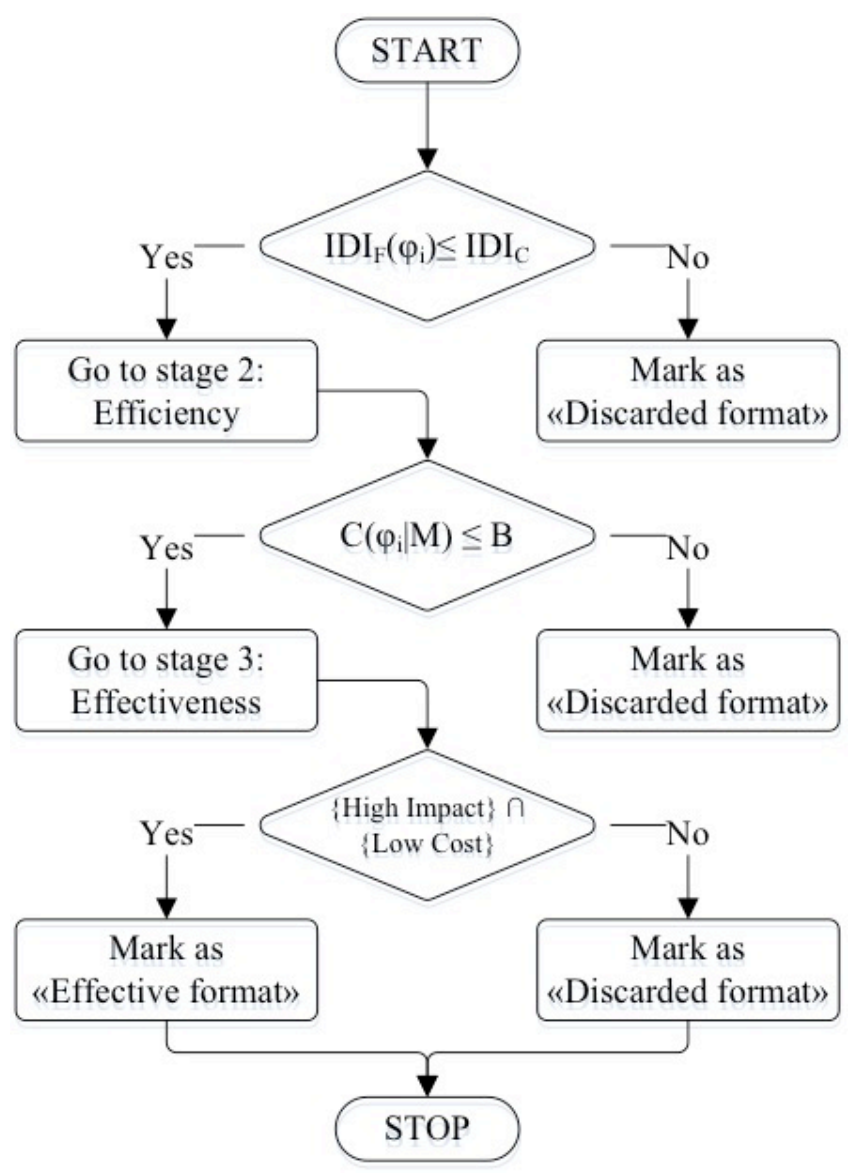

Figure 5. Three-stage-approach full flowchart. 


\section{Practical case study}

In order to highlight the applicability of this three-stage model, we now analyze the case-study of an Italian startup set up in September 2013. The aim of this startup is to exploit new mobile technologies in order to facilitate the creation of a new contingent work market. In order to apply the three-stage approach we need just two pieces of information about the startup: business activity classification and resource availability. The first one can be obtained from the small description above and, using matrix reported into Table 3, the startup can be classified as "generic mobile". In fact it can be classified as "generic purpose" because its market is mainly composed of contingency workers, so it is not related to a specific work class. Moreover it operates in e-business through web community and crossplatform mobile app, so it can be classified as "web \& mobile application". The second piece of information can be obtained from the startup's income statement and balance sheet. In this case we are analyzing an early-stage startup so level of funding will be higher than equity.Values presented in Table 5 are extracted from the balance sheet (indicating with $100 \%$ the total availabilities).

\begin{tabular}{lc} 
Type & Percentage \\
\hline Equity & $8,3 \%$ \\
Funds & $91,7 \%$ \\
Debt & $0,0 \%$ \\
Tot. Availabilities & $100,0 \%$ \\
\hline
\end{tabular}

Table 5. Balance sheet highlights.

According to the model introduced above, $20 \%$ of the firm's available funds should be allocated to advertising. Traditional literature (Beesley, 2012; Christine, 2013) however puts this figure at around 10\% for early stage startups, which may be underestimating the optimum amount needed for their advertising strategy to be successful. Finally, the startup market is concentrated in the city of Rome that is one of the most developed ICT areas of the nation. For this reason, in accordance with paragraph 2, IDIC has been increased to 7.5 , versus the Italian average of 6.28 (International Telecommunication Union, 2012).

Thus, the three-stage approach described in this paper can be applied to identify a tailored advertising strategy, using the following data:

- $\quad$ Startup type (Table 3), Generic mobile;

- $\quad$ Budget (Table 5), 20,0\%;

- $\quad$ IDIC corrected value, 7.5.

\section{I Feasibility: IDI evaluation}

The first stage looks at the comparison between IDIC and IDIF. Using an IDI CC of 7,5, the "Mobile (App)" format (IDIF of 8 ) can be discarded. Between advertising formats classified as "Mobile (App)", in-app advertising (or the practice of including banner ads within apps for smartphones) is surely the most common. Additionally, other techniques such as in-game advertising, push notifications or location-based services, can be exploited on a mobile device, such as a smartphone (Leppäniemi \& Karjaluoto, 2005).

Formats suitable after "Feasibility stage": outdoor, newspaper, magazines, radio, TV, Mobile (SMS), sponsorship, display ads, rich media, direct mail, SEO \& SEM, blogging, social media, digital media.

\subsection{Efficiency: Costs evaluation}

The second stage focuses on the cost of advertising formats. According to the advertising budget (B) previously calculated, print-related formats (papers and magazines), radio and TV can be discarded. Therefore remaining formats have been evaluated as sustainable formats.

- $\quad$ Formats suitable after "Feasibility stage": outdoor, Mobile (SMS), sponsorship, display ads, rich media, direct mail, SEO \& SEM, blogging, social media, digital media.

\subsection{Effectiveness: Impact/Costs evaluation}

Finally the third and last stage analyzes the effectiveness of advertising formats by examining the ratio between impact and cost. This evaluation is based on the startup classification outlined in Table 3. In this case, the startup can be categorized as "generic mobile". Using Table 4, social media and mobile are considered to be the most important advertising formats. However the second one has been discarded in the first stage and therefore will not be considered below. In line with these considerations it is possible to build the effectiveness matrix, reported in Table 6.

\begin{tabular}{|l|l|l|}
\hline & $\begin{array}{l}\text { Low } \\
\text { Expensive }\end{array}$ & $\begin{array}{l}\text { High } \\
\text { Expensive }\end{array}$ \\
\hline High Impact & $\begin{array}{l}\text { SEO \& SEM } \\
\text { Blogging } \\
\text { Social Media } \\
\text { Sponsorship }\end{array}$ & Outdoor \\
\hline $\begin{array}{l}\text { Low } \\
\text { Impact }\end{array}$ & $\begin{array}{l}\text { Mobile (SMS) } \\
\text { Direct Mail } \\
\text { Digital Video }\end{array}$ & $\begin{array}{l}\text { Rich Media } \\
\text { Display Ads }\end{array}$ \\
\hline
\end{tabular}

Table 6. Startup effectiveness matrix.

ISSN: 07I 8-2724. (http://www.jotmi.org) 
The effectiveness matrix shown above suggests that the majority of the advertising budget should be invested in "blogging" (for example, to build an effective website layout I design and maintain up-to-date content) and "social media", supported by a SEO \& SEM campaign to ensure high visibility. At the same time, sponsorship activities may represent an important and effective choice to supply "off-line users". All the other advertising formats, except "outdoor", have been classified as "low impact": this choice is also supported by Nielsen quarterly report on advertising formats (Nielsen, 20lI). Outdoor advertising, instead, results as "highly expensive" because this type of format has a very high cost per impression. Evaluation model results are listed stage-bystage in Figure 6.
The startup started its promotion activities before this analysis by trying out many different advertising formats in order to identify the best combination of them. Evidences show that offline formats such as newspapers, flyers and direct marketing are less effective than online formats with respect to the cost/benefits ratio. Best results were achieved through online formats because of their lower cost and their capability to engage users while they are using a computer or a smartphone, allowing them to try the service on offer. These findings match perfectly with the strategy proposed by this study and thus, the startup has recently decided to invest in SEO \& SEM and social media.

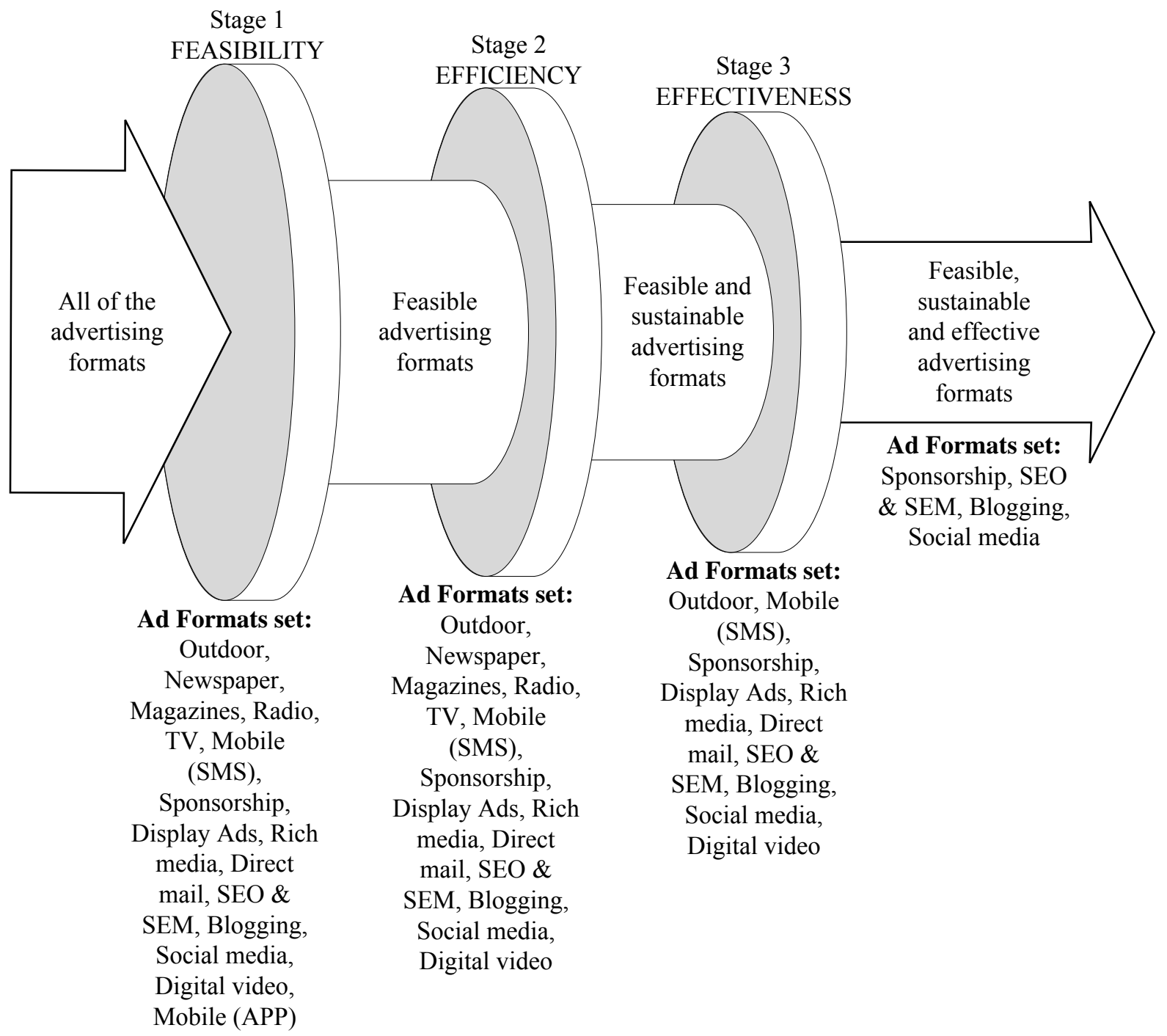

Figure 6. 3-stage-approach practical application. Stage-by-stage evolution and results.

ISSN: 07 I 8-2724. (http://www.jotmi.org) 


\section{Conclusions and future research}

The study proposes an innovative model to evaluate and choose the best advertising format for startups based on a review of existing literature about entrepreneurial and PMI marketing, and most used promotional approaches. It highlights the importance of these elements for a startup in order to both reach its intended market and also to invest its resources on the most efficient advertising formats. A threestage process has been developed to help startups decide on the most effective advertising strategy. The model is based on an assumption, supported by literature, that promotion is mainly influenced by two factors: ICT context evolution and advertising format cost. The first stage evaluates ICT context evolution using the IDIC index. It is an index created by ITU that measures digital divide, taking into account both people skills using ICT instruments. In the second stage, advertising cost is analyzed. In contrast to the first stage, cost evaluation does not need a specific index. In fact it can be directly measured by the entrepreneur: fixed costs of advertising can be inferred through a market analysis, while variable costs (linked to metrics as cost-per-impression or pay-per-click) can be obtained from the startup's business plan. The last stage of the process evaluates the effectiveness of different formats, and considers the ratio between impact and costs.

The assumptions supported by literature, as outlined before, and the quantitative approach of each stage, make the model easy to use in any context (i.e. different context, business, etc.). Finally, the model was tested on a real life example, an ICT startup operating in Italy. The case study validated the simplicity of the model and its effectiveness. In fact, the threestage process implementation suggests that the company should focus on social channels, which are a conventional choice for startups operating in e-business.
Despite the model's assumptions being already acknowledged in literature, there are two main aspects, both concerning IDI use, on which future research should focus:

- $\quad$ The first one is related to IDIF: its value is estimated by logical assumptions but a rigorous method to calculate it has not yet been formalized;

The second one concerns IDIC which is calculated based on national stats, not taking into consideration the differences between different areas of the same nation. Indeed a corrective factor has been used in the presented case study. Despite formula to calculate IDIC has been reported in Table I, it could turn out to be complicated to compute for a specific region, and in fact in the paper it is suggested a manual adjustment based on the national value. In order to overcome this limitation future research could be oriented to develop a new formula to adjust IDIC for specific and smaller areas, characterized by a greater behavioral and technological homogeneity. 


\section{References}

AHUJA, R., Michelis, T., Walker, M., \& Weissbuch, M. (2007, 05 8). Teen perceptions of disclosure in buzz marketing. Journal of Consumer Marketing, 24(3), Pp. I5I-I59. doi: I0.1 I08/073637607|0746/57

ALBERGHINI, E., Cricelli, L., \& Grimaldi, M. (20I3). KM versus enterprise 2.0: a framework to tame the clash. Intrnational Journal of Information Technology and Management, 12(3/4), pp. 320-336. doi: I0.1504/ijitm.20I3.054799

BEESLEY, C. (2012, June 4). How to Set a Marketing Budget that Fits your Business Goals and Provides a High Return on Investment. Retrieved from U.S. Small Business Administration: http://www.sba.gov/community/blogs/howset-marketing-budget-fits-your-business-goals-and-provideshigh-return-investmen

BJERKE, B., \& Hultman, C. M. (2004, 02). Entrepreneurial marketing:The growth of small firms in the new economic era. International Journal of Entrepreneurial Behavior \& Research, I0(I/2), I67-I70. doi:I0.II08/I35525504I052I452

BUREAU OF LABOR STATISTICS. (20I2). Business Employment Dynamics: Entrepreneurship and the U.S. Economy. Washington DC: U.S. Department of Labor. Retrieved from http://www.bls.gov/bdm/entrepreneurship/ entrepreneurship.htm

CARSON, D., Cromie, S., McGowan, P., \& Hill, J. (1995). Marketing and Entrepreneurship in SME's. London: Prentice Hall.

CERATI, F., De Cesari, M., Fotina, C., Meazza, M., Micardi, F., Roffero, F., ... Tremolada, L. (20I2). STARTUP NOW! Guida ai nuovi incentivi e al mercato delle imprese innovative. Milano: II Sole 24 ORE.

CHRISTINE, M. (20I3). The CMO Survey: Highlights and Insights - February 2013. C-suite Studies, Fuqua School of Business, Duke University.

DOBELE, A., Toleman, D., \& Beverland, M. (2005, 03). Controlled infection! Spreading the brand message through viral marketing. Business Horizons, 48(2), Pp. I43-I49. doi:10.1016/j.bushor.2004.10.01I

DYE, R. (2000). The Buzz on Buzz. Harvard Business Review(November/December), pp. I39-I 46.
GROENEWEGEN, G., \& de Langen, F. (20I2). Critical Success Factors of the Survival of Start-Ups with a Radical Innovation. Journal of Applied Economics and Business Research, 2(3), Pp. |55-17|.

HERRMANN, B. L., Marmer, M., Dogrultan, E., \& Holtschke, D. (20I2). Startup Ecosystem Report 20I2. Telefonica Digital and Startup Genome.

HÜSING, T., \& Selhofer, H. (2004). DIDIX: Digital Divide Index for Measuring Inequality in IT Diffusion. I (7), pp. 2I-38.

INTERNATIONAL TELECOMMUNICATION UNION. (20I2). Measuring the Information Society. Geneve: ITU.

JOHNSON, T., \& Kaye, B. (2002, 09 I). Webelievability: A Path Model Examining How Convenience and Reliance Predict Online Credibility. Journalism \& Mass Communication Quarterly, 79(3), pp. 619-642. doi:10.1 I77//07769900207900306

KORTUM, S., \& Lerner,J. (2000).Assessing the contribution of venture capital to innovation. RAND Journal of Economics, 3I (4), pp. 674-692. doi: 10.2307/2696354

KRAUS, S., Harms, R., \& Fink, M. (20I0). Entrepreneurial marketing: moving beyond marketing in new ventures. International Journal of Entrepreneurship and Innovation Management, I I (I),pp. I9-34. doi: I0.I504/ijeim.20I0.029766

LASCH, F., Le Roy, F., \& Yami, S. (2007, 02 I3). Critical growth factors of ICT start-ups. Management Decision, 45(I), pp. 62-75. doi: |0.1| |08/0025|7407|07|8962

LEPPÄNIEMI, M., \& Karjaluoto, H. (2005). Factors influencing consumers' willingness to accept mobile advertising: a conceptual model. International Journal of Mobile Communications, 3(3), pp. 197-2/3. doi:10.1504/ ijmc.2005.006580

LEVINSON,J.(1984). Guerrilla Marketing: Secrets for making big profits from your small business. Boston: Houghton Mifflin.

LEVINSON, J., \& Levinson, J. (20I I). The best of guerilla marketing: Guerilla Marketing remix. USA: Entrepreneur Press.

LEWRICK, M., Omar, M., \& Williams, Jr., R. (20II). Market Orientation and Innovators' Success: an Exploration of the Influence of Customer and Competitor Orientation. Journal of Technology Management \& Innovation, 6(3), pp. 48-62. doi: | 0.4067/s07|8-272420II000300004 
MAGRI, S. (2009). The Financing of Small Innovative Firms: The Italian Case. SSRN Electronic Journal, I8(2), pp. I8I-204. doi:10.2139/ssrn. 1022522

MALDONADO,M.U.,Dias, N.,\&Varvakis, G.(2009).Managing Innovation in Small High-technology Firms: A Case Study in Brazil. Journal of Technology Management \& Innovation, 4(2), Pp. |3 |- | 42. doi: | 0.4067/s07 | 8-272420090002000 I I

MARQUES, C. S., \& Ferreira, J. (2009). SME Innovative Capacity, Competitive Advantage and Performance in a 'Traditional' Industrial Region of Portugal. Journal of Technology Management \& Innovation, 4(4), Pp. 53-68. doi:|0.4067/s07| 8-27242009000400005

MCGRATH, R. G.,Tsai, M.-H.,Venkataraman, S., \& MacMillan, I. C. $(1996,03)$. Innovation, competitive advantage and rent: A model and test. Management Science, 42(3), pp. 389-403. doi:I0.1287/mnsc.42.3.389

MOHR, J., \& Spekman, R. (1994, 02). Characteristics of partnership success: Partnership attributes, communication behavior, and conflict resolution techniques. Strategic Management Journal, 15(2), PP. I35-152. doi:10.1002/ smj.4250I50205

MORRIS, M. H., Schindehutte, M. S., \& LaForge, R.W. (2002). Entrepreneurial marketing: a construct for integrating emerging entrepreneurship and marketing perspectives. Journal of Marketing Theory and Practice, 10(4), pp. I-19.

NIELSEN. (20II). Global AdView Pulse (Q3 20II). Amsterdam: Nielesn.

ORGANISATION for Economic Co-operation and Development. (200I). Understanding the Digital Divide. Paris: OECD Publications.

PHELPS, J., Lewis, R., Mobilio, L., Perry, D., \& Raman, N. (2004). Viral Marketing or Electronic Word-of-Mouth Advertising: Examining Consumer Responses and Motivations to Pass Along Email. Journal of Advertising Research, 44(4), pp. 333348. doi: I0.1017/S002 I84990404037|

PORTER, L., \& Golan, G. (20120). From Subservient Chicken to Brawnt Men: A Comparison of Viral Advertising to Television Advertising. Journal of Interactive Advertising, 6(2), pp. 26-33. doi: 10.1080/I5252019.2006.10722II6

PRICEWATERHOUSECOOPERS LLP. (20II). IAB Internet Advertising Revenue Report (20II Full Year Report). New York: PwC New Media Group.
ROMANELLI, E. (1989, 09). Environments and Strategies of Organization Start-Up: Effects on Early Survival. Administrative Science Quarterly, 34(3), pp. 369-387. doi: $10.2307 / 2393 \mid 49$

SCHWIENBACHER, A., \& Larralde, B. (2010). Crowfunding of Small Entrepreneurial Ventures. In D. Cumming, The Oxford Handbook of Entrepreneurial Finance (p. 752). Oxford: Oxford University Press. doi: 10.2139/ssrn. 1699183

SOHL, J. E., \& Rosenberg, W. (2003, 0I). The US Angel and Venture Capital Market: Recent Trends and Developments. Journal of Private Equity, 6(2), Pp. 7-17. doi:10.3905/ jpe.2003.320035

SONG, M., Bijl van der, H., \& Halman, J. (2008, 12 07). Succes Factors in New Ventures:A Meta-analysis. Journal of Product Innovation Management, 25(I), Pp. 7-27. doi: 10.1 I I I/j.15405885.2007.00280.x

STEENKAMP, N., \& Kashyap, V. (2010, 07 27). Importance and contribution of intangible assets: SME's managers' perceptions. Journal of Intellectual Capital, II(3), pp. 368390. doi: I0.II08/I46919310II064590

STOKES, D. (2002, 04). Entrepreneurial Marketing in the Public Sector:The Lessons of Headteachers as Entrepreneurs. Journal of Marketing Management, I8(3/4), Pp. 397-4I4. doi:I0.1362/0267257022872488

TAN, H., Plowman, D., \& Hancock, P. (2008, 10 17). The evolving research on intellectual capital.Journal of Intellectual Capital, 9(4), pp. 585-608. doi: I0.1 I08/I469/9308/09/3 I77

VENTURE CAPITAL MONITOR. (20II). Rapporto Italia 20II.Varese: Università Carlo Cattaneo.

WATTS, D., \& Peretti, J. (2007). Viral Marketing for the Real World. Harvard Business Review, May, Pp. I-2. doi:10.1007/978-3-8349-9537-7

WONG, A., Bhatia, M., \& Freeman, Z. (2010, 05 10). Angel Finance, The Other Venture Capital. Investment Strategies, Structures, and Policies, PP. 7I-II0. doi: I 0.1002/978 | | 8266908.ch5

ZERENLER, M., Hasiloglu, S. B., \& Sezgin, M. (2008). Intellectual Capital and Innovation Performance: Empirical Evidence in the Turkish Automotive Supplier. Journal of Technology Management \& Innovation, 3(4), Pp. 31-40. doi:10.4067/ s07|8-27242008000200003 
ZILBER, S. N., \& Braz de Araújo, J. (20I2). Small Companies Innovations in Emerging Countries: E-Business Adoption and its Business Model. Journal of Technology Management \& Innovation, 7(2), PP. 102-1/6. doi:10.4067/s07/827242012000200009 